\title{
The Concept of Criminal Liability in Several Criminal Issues in Indonesia in Respect to the Political Directions of Corporate Criminal
}

\author{
Diana Lukitasari ${ }^{1}$ \\ ${ }^{1}$ Universitas Sebelas Maret \\ Surakarta, Indonesia \\ Diana_lukita@staaf.uns.ac.id
}

\begin{abstract}
The development of mandatory criminal sanctions necessitates research investigations and considerations of the type, measure, and subject of the individual who commits a crime. As a result of this finding, the imposition of criminal sanctions in various Indonesian legislation differed. The findings of the study reveal that in Indonesia, the notion of criminal culpability is applied to a variety of criminal law issues with adjustments made between action and punishment. The appropriateness is based on the criminal law master rule and the criminal law categorization of actions. One of the goals of the legal politics direction is determining the danger of criminal sanctions. The government's alignment as a legislator to the society by providing protection and enhancing welfare would then be observed by the political direction in drafting criminal sanctions against business actors.
\end{abstract}

Keywords- Criminal liability, criminal law issues, legal politics, corporations.

\section{INTRODUCTION}

The legal policy of the state in enacting laws and regulations influences the formation of criminal sanctions. As a legislative body, the House of Representatives and the President are responsible for this topic. The establishment of rules and regulations should be interpreted in reality, not just as a written policy in the form of das solen articles (das sein). As a result, certain political interests can participate in the formation of laws and regulations. These interests have an impact on how articles are written, materials are used, and how they are implemented.[1]

Policies in the context of governance, according to Black's Law Dictionary 2nd Edition, are the general principles by which a government is governed while administering its public sphere or taking legislative acts. When used to laws or regulations, this language denotes a broad goal or trend that is thought to be directed at that policy. The basic principle of lawmakers in designing criminal punishments on the basis of function, proportion, and rationale is known as the policy of deciding the crime, and it refers to the principles in general norms and laws. These rules, as well as other general guidelines for the formulation of laws and regulations, can be controlled in Book I of the Criminal Code (KUHP). [2]

In this regard, Anselm von Feuerbach stated that the most important concept for imposing criminal penalties is that every criminal verdict by a judge is a lawful consequence of a legal provision aimed at protecting individual rights. Individuals who break the law must face criminal penalties, such as suffering, as stipulated by the law. The purpose of sentencing, which appears to be a combination of theoretical objectives, namely psychological general prevention (psychologische dwang generale preventie) and special prevention (speciale preventie), was developed by the authors of the Criminal Code so that criminal acts are not repeated by the perpetrators. In the hopes that, in the future, criminals will learn to restrict themselves, and that there will be no more criminals, because the purpose of criminal punishments is to teach and improve.[3]

In Article 51 and Article 52 of the 2019 Criminal Code Bill, the purpose of sentencing is regulated as follows: preventing criminal acts by enforcing legal norms for the community's protection; socializing the convicts by conducting coaching classes in order to make good and useful people; resolving conflicts caused by criminal acts, restoring balance, and bringing a sense of peace in society; and releasing the convicts' guilt. The punishment is not intended to cause pain or to degrade human dignity.[4]

The steps of learning the pattern of punishment are laid out in legislation when it comes to criminal conduct. The Criminal Code has become the major reference for the pattern of punishment in Indonesia, 
as well as the opinions of professionals and scholars who identify criminal crimes, since it was originally promulgated in 1946. Meanwhile, according to Wirjono Prodjodikoro, the classification of criminal conduct under the Criminal Code is based on the violation of qualitatively protected interests. Criminal acts are classified according to protected interests (the interests of people, groups, and the state).[5]

The classification of criminal acts is used as a guide for categorizing the determination of criminal patterns into many categories so that the protected interests' qualifications can be distinguished. Criminal patterns include criminal determinations involving corporate subjects, minors in confrontation with the law, laws other than the Criminal Code, and regional regulations. The severity of the criminal sanction is directly proportionate to the severity of the pattern, as follows: moderate, light, medium, heavy, and severe (serious). The type of crime, as defined by its classification, determines the type of criminal consequence. Depending on the categorization, a criminal sentence can include imprisonment, imprisonment plus a fine, or a fine. Following a review of the legal interests that are protected, the classification is done using the five weights.[6]

Protection of legal interests exists, according to Remmelink, because it encompasses immediate risk (an emergency). It is distinguished from interests that must be protected due to the threat of future harm (gevaarzetting delicten/future danger), such as pornography, theft, and murder. Such action may be inconvenient or harmful, but it must protect the interest. The legislator must focus on acts of hurting, harming, and endangering (life, body, or property) or producing riots (demonstrations or riots) in order to establish the protection of legal interests. [7]

Then, under Article 103 of the Criminal Code, legislators have the authority to pursue other options/commit criminal irregularity not related to the sort of offense that has been determined. This is due to Article 103 of the Criminal Code, which allows legislators (who are not bound by the Criminal Code) to propose exceptions. Alternative actions or deviations are usually only taken when extra penalties are imposed, such as revocation of licenses, seizure of state assets, closure of all or part of a company (for corporations), and so on.[8]

There are no explicit cumulative or minimum penalties in the Criminal Code. Alternative punishments are frequently imposed by legislators outside of the Criminal Code, such as defining a special minimum for imprisonment or fines. This step is taken to give criminal weighting to crimes that are extremely hazardous or harmful to others. Take, for example, the law prohibiting the commission of terrorism or corruption. Since the Criminal Code is the only source of information on the punishment of individuals or groups of individuals. The determination of the criminal in the context of business law is a departure.[4]

Article 18-23 of the Criminal Code, which governs detention, states that it may be imposed for a period ranging from one day to one year, and that it is generally applied for infractions. Individuals who are facing incarceration can better their situation on their own dime. Fines can be substituted for detention, and vice versa.

\section{FINDINGS AND DISCUSSION}

The Establishment of Legislation Regulations Law No. 12 of 2011 governs the creation of criminal provisions. Criminal provisions include formulations that include prohibitions and directives, allowing for the imposition of criminal consequences for infractions. The principle of criminal provisions in Book I of the Criminal Code must be considered while drafting criminal provisions, because this principle also applies to activities that can be punished under other laws, unless otherwise specified (Article 103 of the Criminal Code).[9]

When determining the length of a criminal sentence or the amount of a fine, the effects that may occur in society as well as the element of wrongdoing by the culprit must be taken into account. Criminal provisions must strictly govern and include articles that regulate the violations of prohibitions or commands. As a result, it is required to refrain from referring to other laws and regulations' criminal provisions. Furthermore, if there are no features in common, it is vital to avoid referring to the Criminal Code. It must also avoid discrepancies or omissions in the norms established in the preceding article in order to prepare their own formulation, with the exception of particular crimes.[10]

The choice of terms for each subject of the perpetrator is dictated by the context of the subject of the perpetrator of a crime. If the criminal provisions apply to everyone, the phrase "everyone" is used. If the criminal laws only apply to specified people, such as foreigners, public workers, witnesses, directors, commissioners, and others, they must be clearly stated. Corporations are likewise capable of doing criminal activities. Legal organizations such as corporations, associations, foundations, or cooperatives; and/or the giver of orders to commit a crime or who serves as a leader in committing a crime are all subject to criminal penalties for criminal activities performed by corporations. If Article 33 of the Criminal Code makes a distinction between a criminal offense and a criminal offense, the formulation of criminal laws must tightly govern the qualifications of activities that are threatened with a crime as violations or crimes.[11] 
The criminal provisions must clearly explain whether the penalty imposed is cumulative, alternative, or alternative cumulative. The elements of a cumulative or alternative criminal act must be clearly shown in the formulation of criminal regulations. If a legislative rule including criminal elements would apply retrospectively, the criminal provisions must be excluded.[12]

This is based on the legality principle in Article 1 paragraph (1) of the Criminal Code, which provides that criminal legislation cannot be enforced retrospectively. The criminal provisions must clearly explain whether the penalty imposed is cumulative, alternative, or alternative cumulative. The elements of a cumulative or alternative criminal act must be clearly shown in the formulation of criminal regulations. If a statutory rule including criminal elements is to be implemented retroactively, the criminal provisions must be excluded. This is based on the legality principle in Article 1 paragraph (1) of the Criminal Code, which provides that criminal legislation cannot be enforced retrospectively.[13]

Even though they contain a variety of criminal sanctions because they consist of various types of crimes or as particular crimes, laws other than the Criminal Code might be used as a comparison. There are various types of laws that contain criminal provisions, and it is not typical for the laws in letters $\mathrm{d}$, e, and $\mathrm{f}$ to have criminal provisions, whereas the laws in letters $\mathrm{b}, \mathrm{c}, \mathrm{g}$, and $\mathrm{h}$ allow for criminal provisions to be included.[14]

The criminal provisions of Law letter an are organized differently than those in Law letters b, c, $\mathrm{g}$, and $\mathrm{h}$. Other criminal law statutes have the same basic content as the Criminal Code, but they differ significantly and officially from the Criminal Code and the Criminal Procedure Code. Then there are differences in assessing the criminal sanction in special criminal law (such as special and cumulative minimum requirements). The severity of the threat of criminal penalties for violations of administrative or civil law is determined by the nature of the illegal act.[15]

In determining the criminal provisions, for example, in Article 36 paragraph 1 of Law Number 7 of 2011 concerning Currency, for reasons of a special law, the act of counterfeiting money is sentenced to a special minimum penalty (10 years imprisonment, while Article 245 of the Criminal Code on counterfeiting money carries a maximum penalty of 15 years in prison). In the meantime, Article 4 of Law No. 8 of 2010 on the Prevention and Eradication of the Crime of Money Laundering specifies the highest general consequence (a maximum sentence of 20 years in jail) for violating the Criminal Code's pattern.[6]

The penal provisions for activities that are not the same size are the same under Articles 101 and 102 of Law Number 32 of 2009 concerning
Environmental Protection and Management. Article 101 regulates a person who releases genetically engineered products into the environment in violation of environmental laws or permissions, which can be believed to be damaging to the environment genetically modified products/creatures. Meanwhile, Article 102 governs a person who manages, stores, or owns B3 garbage without a permit, assuming that he does so covertly. The two articles appear to have different weights of loss at first glance, however they both carry the same criminal penalty: imprisonment for a minimum of one year and a maximum of three years, as well as a fine of Rp. 1,000,000,000 (one billion rupiah)-Rp. $3,000,000,000 .[16]$

Legal politics, according to Sudarto, is an effort to develop important norms based on the situation and conditions, as well as state policies, through authorized agencies and institutions. The regulation is expected to be used to demonstrate societal ideals and achieve the desired outcomes. Legal politics (legal policy), according to Moh. Mahfud MD, is an official policy that will be used to attain state goals by enacting new laws and repealing old ones. Legal politics, according to this perspective, is a basic series and assertion of the authority holder's will that includes the politics of establishing, determining, implementing, and enforcing the law. This comprises institutional functions and law enforcement guidance in defining goals.[17]

'Criminal law politics' is also referred to as 'criminal law policy.' The word 'policy' comes from the Dutch word 'politiek' (Dutch). The word 'criminal law politics' is also known by other names in foreign literature, such as 'penal policy,' 'criminal law policy,' or'strafrechtpolitiek.' Modern criminal policy is predicated on the premise that crime is a social truth brought about by human behavior. After a crime has been legally determined, the process of dealing with it does not end there. Criminal law politics is primarily concerned with how criminal legislation can be formulated, administered, and utilized as a guide.[18]

In addition to comprehension, the concept of criminal politics can also be used to express criminal law politics. Combating crime necessitates a calculated political criminal endeavor (criminal policy). Criminal politics is a discipline of research with practical goals in mind, such as improving the formulation of positive legal rules and providing assistance to courts and those who carry out court rulings. Criminal politics has a broad connotation in law enforcement policy, as part of social politics (social policy), as an endeavour by the state to improve the welfare of its citizens. The strategy to combat crime (criminal policy) enshrined in numerous Indonesian laws is an integral aspect of the policy to protect society (social defense policy), which is aimed at ensuring the community's rights are respected (social rights). As a result, criminal 
law politics can be viewed as a policy that must be implemented in the fight against crime in order to preserve the public interest, in this case the community.[19]

The identification of corporate legal subjects who can be held accountable in the form of criminal sanctions reflects the true nature of community protection. Corporations, in this case, are technically created bodies that are permitted to develop their agenda of operations in specific ways due to their legal and political position. The ability to do business; the ability to arrange ownership in specific ways; the ability to attract investment through various incentives, and so on, are all examples of corporate activity. These corporate actions provide opportunities for criminal loopholes to be created, allowing the corporation to be included as a subject of criminal prosecution.[20]

\section{CONCLUSION}

The imposition of a crime is carried out as an instrument to bring about justice, according to the notion. Researching and studying a sentence to suit the perpetrator's acts is how the notion of criminal responsibility is applied to various criminal law concerns in Indonesia. The appropriateness is based on the criminal law master regulation (KUHP) and is classified based on the opinions of criminal law specialists. Adaptations for establishing the formulation of criminal penalties include adopting various methods of criminal/deviation from Article 10 of the Criminal Code, specific minimums or general maximums, administrative crimes, and examining the unlawful act of nature. The government, through its legislative responsibility, remains on the side of the community by safeguarding and advancing the welfare of the public interest.

\section{REFERENCES}

[1] D. R. Jatmiko, Hartiwiningsih, and G. A. K. R. Handayani, "A political communication regulation model in local leaders election and legislative election for realizing a just political education," Int. J. Adv. Sci. Technol., vol. 28, no. 20, pp. 349-352, 2019.

[2] S. Siddik, "The Origin of the Indonesian Blasphemy Law and its Implication towards Religious Freedom in Indonesia The Origin of the Indonesian Blasphemy Law and its Implication towards Religious," no. August, pp. 0-19, 2016.

[3] L. C. Lintang, Adriano Martufi, and J.W. Ouwerker, "The Alternative Concepts of Blasphemy Law in Indonesia: Legal Comparison with Ireland and Canada," Bestuur, vol. 8, no. 2, pp. 121-128, 2020.

[4] I. Freckelton QC, "Blasphemy law, mental illness and the potential for injustice: a cautionary tale from Indonesia," Psychiatry, Psychol. Law, vol. 27, no. 2, pp. 169-180, 2020.

[5] Syahlan, "Effective and Efficient Synchronization in Harmonization of Regulations Indonesia," $J$. Hum. Rights, Cult. Leg. Syst., vol. 1, no. 1, pp. 54-
70,2021

[6] S. D. Baranyanan, "Simplification of Law Regulations in Copyright Criminal Act Settlement," J. Hum. Rights, Cult. Leg. Syst., vol. 1, no. 2, pp. 8091, 2021

[7] A. K. Jaelani and R. D. Luthviati, "The Crime Of Damage After the Constitutional Court's Decision Number 76 / PUU-XV / 2017," J. Hum. Rights, Cult. Leg. Syst., vol. 1, no. 1, pp. 31-41, 2021.

[8] R. D. Luthviati, "The Role of Local Governments in the Defense of Leading Products Resti," J. Best., vol. 8, no. 2, pp. 121-128, 2020.

[9] N. Hasan, "Religious diversity and Blasphemy Law: Understanding growing religious Conflict and intolerance in Post-Suharto Indonesia1," $\mathrm{Al}$ Jami'ah, vol. 55, no. 1, pp. 105-126, 2017.

[10] A. D. Nuryanto, "Problem Penyidikan Tindak Pidana Pencucian Uang yang Berasal dari Predicate Crime Perbankan," Bestuur, vol. 7, no. 1, p. 54, 2019.

[11] T. Triwanto and E. Aryani, "The Urgency of Granting Authority to Assess Corruption Justice Collaborators," Bestuur, vol. 8, no. 1, p. 60, 2020.

[12] S. Gunawan, "The Principle of Control Non Primary Gun System of the Indonesian National Army Protect Soldiers," Bestuur, vol. 8, no. 2, p. 152, 2020.

[13] Z. O. Jainah and I. G. A. K. R. Handayani, "Religious terrorism," Int. J. Adv. Sci. Technol., vol. 28, no. 20, pp. 500-506, 2019.

[14] U. K. Mishra and A. Negi, "Transgender and the Right to Employment in India: Analysing the Trajectories of Discrimination," Bestuur, vol. 9, no. 1, pp. 34-43, 2021.

[15] N. J. Santaularia, R. Larson, and C. Uggen, "Criminal punishment and violent injury in Minnesota," Inj. Epidemiol., vol. 8, no. 1, pp. 1-11, 2021.

[16] L. E. Susanti, "Economic Law Creation Beautiful Global Indonesia," Bestuur, vol. 7, no. 1, p. 47, 2020.

[17] Yuliandri, G. A. K. R. Handayani, T. Prasetyo, K. Seregig, and H. Tegnan, "Retributive justice theory and the application of the principle of sentencing proportionality in Indonesia," J. Leg. Ethical Regul. Issues, vol. 21, no. 4, pp. 1-8, 2018.

[18] C. Fuad, "The curious case of the blasphemer: Ambiguity as literary device in leviticus 24:10-23," Horizons Biblic. Theol., vol. 41, no. 1, pp. 51-70, 2019.

[19] Z. N. Rosidah, "Coherence of the Rules of Sharia Against Pancasila," Bestuur, vol. 8, no. 1, p. 40, 2020.

[20] L. Kajoko, Z. N. Rosidah, and I. G. A. K. R. Handayani, "Refleksi Paradigma Ilmu Pengetahuan Bagi Pembangunan Hukum Pengadaan Tanah," Bestuur, vol. 7, no. 1, pp. 1-14, 2019. 